\title{
Acheter le volume: Shakespeare poète
}

\section{(2) OpenEdition}

1 Journals

\section{Electronic version}

URL: http://journals.openedition.org/shakespeare/1069

DOI: 10.4000/shakespeare.1069

ISSN: 2271-6424

\section{Publisher}

Société Française Shakespeare

\section{Printed version}

Date of publication: 1 November 2007

ISBN: 2-9521475-3-1

\section{Electronic reference}

"Acheter le volume: Shakespeare poète ", Actes des congrès de la Société française Shakespeare [Online], 24 | 2007, Online since 23 February 2008, connection on 06 May 2019. URL : http:// journals.openedition.org/shakespeare/1069; DOI : 10.4000/shakespeare.1069

This text was automatically generated on 6 May 2019.

(c) SFS 


\section{Acheter le volume: Shakespeare poète}

